\begin{tabular}{|c|l|}
\hline Title & Synthesis and crystal structure of K2NiF4type novel Gd1+xCa1-xA IO4 xNx oxynitrides \\
\hline Author(s) & Masubuchi, Y uji; Hata, Tomoyuki; Motohashi, Teruki; Kikkawa, Shinichi \\
\hline Citation & $\begin{array}{l}\text { Journal of alloys and compounds, 582, 823.826 } \\
\text { https://doi.org/10.1016/.jallcom.2013.08.140 }\end{array}$ \\
\hline Issue Date & 2013-01-05 \\
\hline Doc URL & http://hdl.handle.net/2115/54928 \\
\hline Type & article (author version) \\
\hline File Information & JALCom2014582-823-826.pdf \\
\hline
\end{tabular}

Instructions for use 


\title{
Synthesis and crystal structure of $\mathrm{K}_{2} \mathrm{NiF}_{4}$-type novel
}

\author{
$\mathrm{Gd}_{1+\mathrm{x}} \mathrm{Ca}_{1-\mathrm{x}} \mathrm{AlO}_{4-\mathrm{x}} \mathrm{N}_{\mathrm{x}}$ oxynitrides
}

Yuji Masubuchi*, Tomoyuki Hata, Teruki Motohashi, and Shinichi Kikkawa

Affiliation

Faculty of Engineering, Hokkaido University, N13 W8, Kita-ku, Sapporo, Hokkaido 060-8628, Japan

${ }^{*}$ Corresponding author: Y. Masubuchi; Address: Faculty of Engineering, Hokkaido University, N13 W8, Kita-ku, Sapporo 060-8628, Japan; Tel/Fax: +81-(0)11-706-6742/6740; E-mail: yuji-mas@eng.hokudai.ac.jp 
Abstract

Novel gadolinium calcium aluminum oxynitrides, $\mathrm{Gd}_{1+x} \mathrm{Ca}_{1-x} \mathrm{AlO}_{4-x} \mathrm{~N}_{x}$, were prepared in $x=0.15-0.25$ by the solid state reaction of a nitrogen-rich mixture with AIN as an aluminum source; the mixture was sintered twice at 1500 ${ }^{\circ} \mathrm{C}$ for $5 \mathrm{~h}$ under $0.5 \mathrm{MPa}$ of nitrogen gas. Shift in the optical absorption edge was observed in their diffuse reflectance spectra from $4.4 \mathrm{eV}$ for the oxide $(x=0)$ to $2.9 \mathrm{eV}$ for the oxynitride at $x=0.2$. The crystal structure of $\mathrm{Gd}_{1.2} \mathrm{Ca}_{0.8} \mathrm{AlO}_{3.8} \mathrm{~N}_{0.2}$ at $x=0.2$ was refined using a synchrotron $x$-ray diffraction data as a layered $\mathrm{K}_{2} \mathrm{NiF}_{4}$-type structure with the $14 \mathrm{~mm}$ space group. Longer $\mathrm{Al}-\mathrm{O} / \mathrm{N}$ bond lengths in the oxynitride than those in $\mathrm{GdCaAlO}_{4}$ suggest that the nitride ions are in the apical site of aluminum polyhedron, similar to those in $\mathrm{Nd}_{2} \mathrm{AlO}_{3} \mathrm{~N}$.

KEYWORDS: A. inorganic materials, A. rare earth alloys and compounds, B. solid state reactions, C. crystal structure, D. synchrotron radiation, D. X-ray diffraction 


\section{Introduction}

Multinary oxynitride compounds are attracting much attention in applications such as white light emitting diodes (LEDs) [1,2], visible light driven photocatalysts [3,4], inorganic pigments [5,6] and dielectric materials [7-12]. The optical properties of the oxynitrides in the UV-vis range have been explained by the coexistence of nitride and oxide anions together because of the more covalent nature in nitride ion [13]. Much research on phosphor materials for LED applications has been conducted on silicon oxynitride and alumino-silicon oxynitrides as host materials [14-16]. However, study on (oxy)nitrides of especially aluminum is limited to systems such as AIN:Eu, spinel-type AlON:Mg,Mn, and $\mathrm{BaAl}_{11} \mathrm{O}_{16} \mathrm{~N}: \mathrm{Eu}$ [17-19]. Magnetoplumbite-type aluminum oxynitride doped with Eu was reported to be a phosphor material to have emission in multiple wavelength [20]. Neutron diffraction study showed that the emission site split because they have a slightly different coordination in the presence of both nitride and oxide ions together [21].

$R E_{2} \mathrm{AlO}_{3} \mathrm{~N}$ oxynitride $(R E=\mathrm{La}, \mathrm{Nd}, \mathrm{Sm})$ with $\mathrm{K}_{2} \mathrm{NiF}_{4}$-type structure $(n=1$ in Ruddlesden-Popper phase, $A_{n+1} B_{n} X_{3 n+1}$ ) has been prepared by firing mixtures of $R E_{2} \mathrm{O}_{3}$ and AIN in a small sealed nickel tube at a high temperature $\left(1350{ }^{\circ} \mathrm{C}\right)$ 
under $\mathrm{N}_{2}$ flow [22]. Crystal structure refinement of $\mathrm{Nd}_{2} \mathrm{AlO}_{3} \mathrm{~N}$ using its neutron diffraction data showed an ordering of nitride and oxide ions in the reduced symmetry from $14 / \mathrm{mmm}$ in $\mathrm{K}_{2} \mathrm{NiF}_{4}$ to $14 \mathrm{~mm}$ in $\mathrm{Nd}_{2} \mathrm{AlO}_{3} \mathrm{~N}$ [23]. The nitride ion is located at an apical site of $\mathrm{AlO}_{5} \mathrm{~N}$ octahedron. There are two kinds of rare earth sites; $\mathrm{Nd} 1$ coordinated with $\mathrm{O}_{8} \mathrm{~N}$ and $\mathrm{Nd} 2$ coordinated with $\mathrm{O}_{5} \mathrm{~N}_{4}$, as shown in Fig. 1. $\mathrm{Sr}_{2} \mathrm{TaO}_{3} \mathrm{~N}$ crystallizes in $\mathrm{K}_{2} \mathrm{NiF}_{4}$-type structure with $14 / \mathrm{mmm}$ space group. Its nitride ions are located at equatorial sites of $\mathrm{TaO}_{4} \mathrm{~N}_{2}$ octahedron, and there is only one crystallographic Sr site, (4e) [24]. Several kinds of aluminum oxides $A E R E A O_{4}(A E=\mathrm{Ca}, \mathrm{Sr}, R E=\mathrm{La}, \mathrm{Nd}, \mathrm{Sm}, \mathrm{Gd})$ have also been reported to crystallize in $14 / \mathrm{mmm}$ space group [25-27].

The oxynitride was found out in a preparation using a nickel tube. An alternative preparation method, such as the carbon reduction nitridation method, has been applied to prepare $\mathrm{Nd}_{2} \mathrm{AlO}_{3} \mathrm{~N}$ and $\mathrm{Sm}_{2} \mathrm{AlO}_{3} \mathrm{~N}$ [28]. $\mathrm{La}_{2} \mathrm{AlO}_{3} \mathrm{~N}$ and $\mathrm{Gd}_{2} \mathrm{AlO}_{3} \mathrm{~N}$ can be utilized as a multi-color emitting phosphor host material when they will be doped with divalent Eu. They have two crystallographic rare earth sites induced by $\mathrm{O} / \mathrm{N}$ ordering, as mentioned above for $\mathrm{Nd}_{2} \mathrm{AlO}_{3} \mathrm{~N}$. Photoluminescence property of divalent Eu can be controlled by changing its coordination environment such as coordination number and $\mathrm{O} / \mathrm{N}$ ratio. 
In our preliminary study, $\mathrm{La}_{2} \mathrm{AlO}_{3} \mathrm{~N}$ has been tried to obtain in solid state reaction but there was no appearance of the oxynitride in the products prepared using a similar method described in this paper. $\mathrm{Gd}_{2} \mathrm{AlO}_{3} \mathrm{~N}$ has not yet been obtained in the carbon reduction nitridation [28], because the size of the $\mathrm{Gd}^{3+}$ ion is not compatible with the $\mathrm{K}_{2} \mathrm{NiF}_{4}$-type structure. However, the $\mathrm{GdCaAlO}_{4}$ phase is successfully prepared by the simple solid state reaction [29]. The ionic radius of $\mathrm{Gd}^{3+}$ in 9 coordination is $0.124 \mathrm{~nm}$, which is smaller than $\mathrm{Nd}^{3+}(0.130 \mathrm{~nm})$ and $\mathrm{Sm}^{3+}(0.127 \mathrm{~nm})$; however, the mixing $\mathrm{Gd}^{3+}$ with $\mathrm{Ca}^{2+}(0.132 \mathrm{~nm})$ will increase their average size to stabilize $\mathrm{K}_{2} \mathrm{NiF}_{4}$ structure [30]. In this study, a series of $\mathrm{K}_{2} \mathrm{NiF}_{4}$-type gadolinium calcium aluminum oxynitrides, $\mathrm{Gd}_{1+x} \mathrm{Ca}_{1-x} \mathrm{AlO}_{4-x} \mathrm{~N}_{x}$, were prepared by co-substituting $\mathrm{Ca}^{2+}$ and $\mathrm{O}^{2-}$ in $\mathrm{GdCaAlO}_{4}$ with $\mathrm{Gd}^{3+}$ and $\mathrm{N}^{3-}$ simultaneously by the solid state reaction. Their crystal structure was investigated by high resolution synchrotron $x$-ray diffraction analysis.

\section{Experimental}

$\mathrm{Gd}_{2} \mathrm{O}_{3}\left(99.9 \%\right.$, Wako Pure Chemicals Co.), $\mathrm{CaCO}_{3}$ (99.9\%, Wako Pure

Chemicals Co.), $\mathrm{y}^{-\mathrm{Al}_{2} \mathrm{O}_{3}}$ (99.95\%, Kojundo Chem. Lab. Co.), and AIN (Grade H, Tokuyama Co.) were used as starting materials. $\mathrm{Gd}_{2} \mathrm{O}_{3}$ was calcined at $1000^{\circ} \mathrm{C}$ 
for $10 \mathrm{~h}$ before mixing with other powders. The powders were dry mixed in stoichiometric ratios for $\mathrm{Gd}_{1+x} \mathrm{Ca}_{1-x} \mathrm{AlO}_{4-x} \mathrm{~N}_{x}$ with $x=0-0.3$ in a dry nitrogen atmosphere to avoid hydrolysis of AIN with moisture. The mixed powders were uniaxially pressed at $20 \mathrm{MPa}$ to form $10 \mathrm{~mm}$ diameter disks, which were then fired in a gas pressure furnace at $1500{ }^{\circ} \mathrm{C}$ for $5 \mathrm{~h}$ under a nitrogen pressure of $0.5 \mathrm{MPa}$. The aluminum source was either AIN only or a mixture of AIN and $\mathrm{Y}-\mathrm{Al}_{2} \mathrm{O}_{3}$. For $\mathrm{AIN}$ only as the aluminum source, the cation composition, i.e., Gd:Ca:Al = 1+x:1-x:1, was maintained; however, the anionic composition was variable during the reaction. A part of AIN was expected to be oxidized during synthesis process. When $\mathrm{AIN}$ without $\mathrm{y}-\mathrm{Al}_{2} \mathrm{O}_{3}$ was used, the starting mixtures were fired twice with an intermediate grinding and mixing step.

The crystalline phases were characterized by powder x-ray diffraction (XRD; Ultima IV, Rigaku) with monochromatized Cu Ka radiation. XRD patterns were collected over the $2 \theta$ range of $10-120^{\circ}$ with a step size of $0.02^{\circ}$. For structural refinement of $\mathrm{Gd}_{1+\chi} \mathrm{Ca}_{1-x} \mathrm{AlO}_{4-x} \mathrm{~N}_{x}$, high resolution synchrotron powder XRD experiments was performed at room temperature using a Debye-Scherrer camera installed at beamline BL02B2 of the Japan Synchrotron Radiation Institute (SPring-8). The incident beam was monochromatized to $0.035459 \mathrm{~nm}$. 
The finely ground powder samples were put into a $0.2 \mathrm{~mm} \phi$ glass capillary. The Rietveld program RIETAN-FP [31] was used for crystal structure refinement. The crystal structures were visualized using the VESTA program [32]. The nitrogen content was measured with an oxygen/nitrogen analyzer (EMGA-620W, Horiba) using $\mathrm{Si}_{3} \mathrm{~N}_{4}$ as a reference. Diffuse reflectance spectra were measured using a spectrophotometer (V-550, Jasco) in the range of $250-750 \mathrm{~nm}$.

\section{Results and discussion}

3.1. Preparation of $\mathrm{Gd}_{1+x} \mathrm{Ca}_{1-x} \mathrm{AlO}_{4-x} \mathrm{~N}_{x}$ oxynitrides

The products obtained from stoichiometric mixtures using both $\mathrm{y}-\mathrm{Al}_{2} \mathrm{O}_{3}$ and AIN as aluminum source were contaminated with $\mathrm{Gd}_{2} \mathrm{O}_{3}$. A single phase of $\mathrm{Gd}_{1+x} \mathrm{Ca}_{1-x} \mathrm{AlO}_{4-x} \mathrm{~N}_{x}$ with the $\mathrm{K}_{2} \mathrm{NiF}_{4}$-type structure was obtained only at $x=0$, that is $\mathrm{GdCaAlO}_{4}$. Simultaneous substitution of $\mathrm{Ca}^{2+}$ and $\mathrm{O}^{2-}$ pair with $\mathrm{Gd}^{3+}$ and $\mathrm{N}^{3-}$ together led to the $\mathrm{K}_{2} \mathrm{NiF}_{4}$-type oxynitride products with a small impurity phase of $\mathrm{Gd}_{2} \mathrm{O}_{3}$. The amount of the $\mathrm{Gd}_{2} \mathrm{O}_{3}$ impurity phase increased with an increase in $x$. Diffraction lines from the $\left(00 /\right.$ planes of the $\mathrm{K}_{2} \mathrm{NiF}_{4}$-type structure shifted toward a smaller diffraction angle with increasing $x$. Elongation of the $c$-axis has been observed similarly from the $\mathrm{CaNdAlO}_{4}$ oxide $(a=0.36847(3) \mathrm{nm}$ and $c=$ 
1.2124(2) nm) to $\mathrm{Nd}_{2} \mathrm{AlO}_{3} \mathrm{~N}$ oxynitride $(a=0.37046(2) \mathrm{nm}$ and $c=1.25301(13)$ nm) $[23,27]$. The increase of the lattice parameter $c$ suggests the formation of $\mathrm{Gd}_{1+x} \mathrm{Ca}_{1-x} \mathrm{AlO}_{4-x} \mathrm{~N}_{x}$ oxynitride with the $\mathrm{K}_{2} \mathrm{NiF}_{4}$-type structure. The appearance of $\mathrm{Gd}_{2} \mathrm{O}_{3}$ impurity may indicate nitrogen deficiency in $\mathrm{Gd}_{1+x} \mathrm{Ca}_{1-x} \mathrm{AlO}_{4-x} \mathrm{~N}_{x}$ due to partial oxidation of AIN during the synthesis.

The $\mathrm{K}_{2} \mathrm{NiF}_{4}$-type $\mathrm{Gd}_{1+x} \mathrm{Ca}_{1-x} \mathrm{AlO}_{4-x} \mathrm{~N}_{x}$ oxynitride obtained from starting mixtures containing both $\mathrm{y}-\mathrm{Al}_{2} \mathrm{O}_{3}$ and $\mathrm{AIN}$ was contaminated with the $\mathrm{Gd}_{2} \mathrm{O}_{3}$ impurity phase loosing nitrogen during the reaction. Therefore, AIN only was used as the aluminum source in the starting mixtures to improve the phase purity. Single phase of $\mathrm{Gd}_{1+x} \mathrm{Ca}_{1-x} \mathrm{AlO}_{4-x} \mathrm{~N}_{x}$ was obtained between $x=0.15$ and 0.25 as shown in Fig. 2. AIN was expected to be partially oxidized during the synthesis process. The suitable $\mathrm{O} / \mathrm{N}$ ratio was attained to form a pure oxynitride phase between $x=0.15$ and 0.25 in the reaction.

$\mathrm{CaAl}_{2} \mathrm{O}_{4}$ and $\mathrm{Gd}_{2} \mathrm{O}_{3}$ were observed as secondary phases at $x=0.1$ and 0.30 , respectively. The product obtained at $x=0.2$ had an expanded $c$-axis $(a=$ $0.3658(1) \mathrm{nm}$ and $c=1.2067(5) \mathrm{nm})$ compared to that for $\mathrm{GdCaAlO}_{4}(a=$ $0.3658(2) \mathrm{nm}$ and $c=1.1994(6) \mathrm{nm})$ at $x=0$. The nitrogen content of the $x=0.2$ oxynitride was 1.2(1) wt\%, which is comparable with the theoretical nitrogen 
content of 0.9 wt $\%$ within $\pm 3 \sigma$. The $x=0.20$ oxynitride was expected to have an $\mathrm{O} / \mathrm{N}$ ratio of 3.8/0.2 to maintain the charge neutrality. The lattice expansion may be due to partial substitution of $\mathrm{O}^{2-}(r=0.124 \mathrm{~nm}, \mathrm{c} . \mathrm{n} .=4)$ by $\mathrm{N}^{3-}(r=0.134 \mathrm{~nm}$, c.n. = 4), although $\mathrm{Gd}^{3+}(r=0.124 \mathrm{~nm}, \mathrm{c} . \mathrm{n} .=9)$ is smaller than $\mathrm{Ca}^{2+}(r=0.132$ nm, c.n. = 9) [30]. Anisotropic expansion along the $c$-axis implies the ordering of nitride ions in the apical sites of $\mathrm{AlO}_{5} \mathrm{~N}$ octahedron, similarly to the crystal structure reported for the $\mathrm{Nd}_{2} \mathrm{AlO}_{3} \mathrm{~N}$ oxynitride with fully ordered nitride ions on the apical site (2a), as shown in Fig. 1(a) [23].

The color of the resultant oxynitrides was yellow, while $\mathrm{GdCaAlO}_{4}$ was white. The absorption edges were at ca. $4.46 \mathrm{eV}$ and $2.94 \mathrm{eV}$ for the oxide $(x=$ $0)$ and oxynitride $(x=0.2)$, respectively, as shown in Fig. 3. The color change occurred with the nitrogen incorporation to form a new valence band at higher energy position than $O(2 p)$ orbital level, as reported for many oxynitride pigments $[5,6,13]$. The edge positions of the oxynitrides obtained at $x=0.15 \sim$ 0.25 slightly shifted toward longer wavelength along with the nitrogen content, $x$. The shift in edge positions indicated a decrease in band gap of $\mathrm{Gd}_{1+x} \mathrm{Ca}_{1-x} \mathrm{AlO}_{4-x} \mathrm{~N}_{x}$, implying an elevated valence band level as increasing in the nitrogen content. Table 1 summarizes the optical band gap energy and lattice 
parameters of the oxynitrides. Ordering of the nitride ions in the apical site of $\mathrm{Al}$ octahedron induces two kinds of $\mathrm{Gd} / \mathrm{Ca}$ sites coordinated with N-rich or N-poor anions as shown in Fig. 1(a). Absorption edge positions can be attributed to the $\mathrm{N}$-rich $\mathrm{Gd} / \mathrm{Ca}$ polyhedron, because of the higher energy level of the nitrogen $2 \mathrm{p}$ orbital than that of oxygen. The decrease in band gap energy might be interpreted as nitrogen enrichment in the former $\mathrm{Gd} / \mathrm{Ca}$ polyhedron. Crystal structure of the oxynitride at $x=0.20$ is discussed in the next section.

\subsection{Crystal structure refinement at the $\mathrm{Gd}_{1.2} \mathrm{Ca}_{0.8} \mathrm{AlO}_{3.8} \mathrm{~N}_{0.2}$ oxynitride}

The crystal structure of $\mathrm{Gd}_{1.2} \mathrm{Ca}_{0.8} \mathrm{AlO}_{3.8} \mathrm{~N}_{0.2}$ was refined using the high resolution synchrotron XRD pattern in the $\mathrm{K}_{2} \mathrm{NiF}_{4}$-type structure with the $14 \mathrm{~mm}$ space group, starting from the reported crystallographic parameters for $\mathrm{Nd}_{2} \mathrm{AlO}_{3} \mathrm{~N}$ [23]. The $\mathrm{O} / \mathrm{N}$ ratios for three anionic sites were fixed at $0.95 / 0.05$, because of their mutually similar $\mathrm{x}$-ray scattering factors. Neutron diffraction has been generally used for analysis of the oxygen and nitrogen distribution in oxynitrides; however, it is not useful for the present products, because the Gd atom has a large neutron absorption cross section. The finally refined parameters from the Rietveld method are summarized in Table 2. Observed, 
calculated, and difference synchrotron XRD profiles for $\mathrm{Gd}_{1.2} \mathrm{Ca}_{0.8} \mathrm{AlO}_{3.8} \mathrm{~N}_{0.2}$ are shown in Fig. 4. The refined occupancies for $\mathrm{Gd} / \mathrm{Ca}$ sites indicate a chemical composition of $\mathrm{Gd}_{1.22(1)} \mathrm{Ca}_{0.78(1)} \mathrm{AlO}_{3.8} \mathrm{~N}_{0.2}$, which is in agreement with the nominal starting composition of $\mathrm{Gd}_{1.2} \mathrm{Ca}_{0.8} \mathrm{AlO}_{3.8} \mathrm{~N}_{0.2}$. The bond lengths and the atomic arrangements around $\mathrm{Al}$ and $\mathrm{Gd} / \mathrm{Ca}$ sites are summarized in Table 3 and shown in Fig. 5(a), respectively. The crystal structure of $\mathrm{GdCaAlO}_{4}$ reported by $\mathrm{L}$. Vasylechko, et al., [26] using a powder XRD pattern is also shown in Fig. 5(b). The oxynitride has $c$-axis much longer than the reported value for $\mathrm{GdCaAlO}_{4}$ (1.19787 nm), while a-axis is almost similar between the oxynitride and oxide. The elongated $c$-axis is attributed to longer Al-O/N2 bond length of $0.2160(18)$ $\mathrm{nm}$ in the oxynitride than the corresponding distance of $0.2027 \mathrm{~nm}$ for $\mathrm{Al}-\mathrm{O}$ in the oxide. Similarly elongated bond lengths have been observed for Al-N bond length in $\mathrm{Nd}_{2} \mathrm{AlO}_{3} \mathrm{~N}$ compared with $\mathrm{NdCaAlO}_{4}$. The nitride ions are located at the apical sites of $\mathrm{AlO}_{5} \mathrm{~N}$ octahedron in $\mathrm{Nd}_{2} \mathrm{AlO}_{3} \mathrm{~N}$ [23]. The bond length of $\mathrm{Al}-\mathrm{N}$ was reported to be $0.1893 \mathrm{~nm}$ for c.n. $=4$ in AIN, which is longer than that of Al-O $\left(0.1710 \mathrm{~nm}\right.$ for c.n. $=4$ in $\left.\mathrm{y}-\mathrm{Al}_{2} \mathrm{O}_{3}\right)[33,34]$. The longer bond lengths of $\mathrm{Al}-\mathrm{O} / \mathrm{N} 2$ indicate the preferential occupation of nitride ions on $\mathrm{O} / \mathrm{N} 2$ sites in the present $\mathrm{Gd}_{1.2} \mathrm{Ca}_{0.78} \mathrm{AlO}_{3.8} \mathrm{~N}_{0.2}$, as reported in $\mathrm{Nd}_{2} \mathrm{AlO}_{3} \mathrm{~N}$ [20]. The preferential occupation 
of nitride ion might elongate the chemical bond between $\mathrm{Gd} / \mathrm{Ca}$ and $\mathrm{O} / \mathrm{N} 2$. On the other hand, the refined bond length is $0.2617(2) \mathrm{nm}$ for $\mathrm{Gd} / \mathrm{Ca} 1-\mathrm{O} / \mathrm{N} 2$ which is comparable to the reported value of $0.2609 \mathrm{~nm}$ in the corresponding oxide. Substitution of $\mathrm{O}^{2-}$ with $\mathrm{N}^{3-}$ can increase the bond length, while smaller $\mathrm{Gd}^{3+}$ cation also replaces a part of bigger $\mathrm{Ca}^{2+}$ cation in the oxynitride. Therefore the bond length between $\mathrm{Gd} / \mathrm{Ca}$ and $\mathrm{O} / \mathrm{N}$ does not change significantly from the oxide to the oxynitride. BVS calculation was performed in the oxynitride. The value is +3.06 for the $\mathrm{Al}$ ion and is larger than theoretical value of +3 , when a random distribution of $\mathrm{O} / \mathrm{N}$ ions on the anion sites is assumed. The BVS value is improved to be +3.01 in the ordering of the nitride ions only in $\mathrm{O} / \mathrm{N} 2$ site, supporting the preferential occupation of nitride ions in O/N2 site. Structure refinement in $14 / \mathrm{mmm}$ space group showed much less agreement with $R_{\text {wp }}$ value of $5.6 \%$. The refined bond length of $\mathrm{Al}-\mathrm{O} / \mathrm{N} 2$ was shorter than that of $\mathrm{Al}-\mathrm{O}$ in the oxide, although the refined $\mathrm{Gd} / \mathrm{Ca} 1-\mathrm{O} / \mathrm{N} 2$ bond length was longer than that in the oxide. Both the poor fitting of the oxynitride and the decrease in the Al-O/N2 bond length of $\mathrm{Al}(\mathrm{O}, \mathrm{N})_{6}$ octahedron exclude the $14 / \mathrm{mmm}$ space group for the structural refinement of the $\mathrm{Gd}_{1.2} \mathrm{Ca}_{0.8} \mathrm{AlO}_{3.8} \mathrm{~N}_{0.2}$ oxynitride. The present oxynitride crystallizes in $14 \mathrm{~mm}$ space group having non-equivalent $\mathrm{Gd} / \mathrm{Ca} 1$ and 
$\mathrm{Gd} / \mathrm{Ca} 2$ sites. Preparation and photoluminescence property of Eu doped $\mathrm{Gd}_{1+x} \mathrm{Ca}_{1-x} \mathrm{AlO}_{4-x} \mathrm{~N}_{x}$ are currently being investigated.

\section{Conclusions}

Novel gadolinium calcium aluminum oxynitrides, $\mathrm{Gd}_{1+x} \mathrm{Ca}_{1-x} \mathrm{AlO}_{4-x} \mathrm{~N}_{x}(x=$ 0.15-0.25), were prepared by the solid state reaction from a nitrogen-rich starting composition. Diffuse reflectance spectra showed the shift in absorption edge from oxide $(4.46 \mathrm{eV})$ to oxynitride at $x=0.2(2.94 \mathrm{eV})$ due to the nitrogen incorporation. The crystal structure refinement of the $\mathrm{Gd}_{1.2} \mathrm{Ca}_{0.8} \mathrm{Al}_{3.8} \mathrm{~N}_{0.2}$ oxynitride using synchrotron XRD showed the elongation of the Al-O/N bond length in aluminum octahedron similar to the $\mathrm{Nd}_{2} \mathrm{AlO}_{3} \mathrm{~N}$, indicating that the nitride ions are preferentially in the apical site of the aluminum octahedron in the oxynitride. The preferential occupation of nitride ion on a specific anion site forms two distinct $\mathrm{Gd} / \mathrm{Ca}$ sites making the oxynitride to future application for a novel muti-color emitting phosphor host material for divalent Eu doping. 


\section{References}

[1] R.J. Xie, N. Hirosaki, K. Sakuma, Y. Yamamoto, M. Mitomo, Appl. Phys. Lett. 84 (2004) 5404-5406.

[2] T. Suehiro, N. Hirosaki, R.J. Xie, M. Mitomo, Chem. Mater. 17 (2005) 308-314.

[3] K. Maeda, K. Domen, J. Phys. Chem. C 111 (2007) 7851-7861.

[4] K. Maeda, T. Takata, M. Hara, N. Saito, Y. Inoue, H. Kobayashi, K. Domen, J. Am. Chem. Soc. 127 (2005) 8286-8287.

[5] M. Jansen, H.P. Letschert, Nat. 404 (2000) 980-982.

[6] M. Pérez-Estébanez, R. Pastrana-Fábregas, J. Isasi-Marín, R. Sáez-Puche, J. Mater. Res. 21 (2006) 1427-1433.

[7] Y.I. Kim, P.M. Woodward, K.Z. Baba-Kishi, C.W. Tai, Chem. Mater. 16 (2004) 1267-1276.

[8] Y.R. Zhang, T. Motohashi, Y. Masubuchi, S. Kikkawa, J. Ceram. Soc. Jpn. $119(2011) 581-586$

[9] Y.R. Zhang, T. Motohashi, Y. Masubuchi, S. Kikkawa, J. Eur. Ceram. Soc. 32 (2012) 1269-1274.

[10] M. Yang, J. Oro-Sole, J.A. Rodgers, A.B. Jorge, A. Fuertes, J.P. Attfield, Nat. 
Chem. 3 (2011) 47-52.

[11] Y. Hinuma, H. Moriwake, Y.R. Zhang, T. Motohashi, S. Kikkawa, I. Tanaka, Chem. Mater. 24 (2012) 4343-4349.

[12] Y.R. Zhang, Y. Masubuchi, T. Motohashi, S. Kikkawa, K. Hirota, Ceram. Int. 39 (2013) 3377-3380.

[13] F. Tessier, P. Maillard, F. Chevire, K. Domen, S. Kikkawa, J. Ceram. Soc. Jpn. 117 (2009) 1-5.

[14] X. Piao, T. Horikawa, H. Hanzawa, K. Machida, Appl. Phys. Lett. 88 (2006) 161908/1-3.

[15] Y. Masubuchi, M. Yoshikawa, T. Takeda, S. Kikkawa, J. Alloys Compd. 487 (2009) 409-412.

[16] X.W. Zhu, Y. Masubuchi, T. Motohashi, S. Kikkawa, J. Alloys Compd. 489 (2010) 157-161.

[17] N. Hirosaki, R.J. Xie, K. Inoue, T. Sekiguchi, B. Dierre, K. Tamura, Appl. Phys. Lett. 91 (2007) 061101/1-3.

[18] R.J. Xie, N. Hirosaki, X.J. Liu, T. Takeda, H.L. Li, Appl. Phys. Lett. 92 (2008) 201905/1-3.

[19] S.R. Jansen, J.M. Migchels, H.T. Hintzen, R. Metselaar, J. Electrochem. 
Soc. 146 (1999) 800-806.

[20] S. Kikkawa, N. Hatta, T. Takeda, J. Am. Ceram. Soc. 91 (2008) 924-928.

[21] Y. Masubuchi, T. Hata, T. Motohashi, S. Kikkawa, J. Solid State Chem. 184 (2011) 2533-2537.

[22] R. Marchand, C. R. Acad. Sci. Paris 282 (1976) 329-331.

[23] R. Marchand, R. Pastuszak, Y. Laurent, G. Roult, Rev. Chim. Miner. 19 (1982) 684-689.

[24] N. Diot, R. Marchand, J. Haines, J. M. LeHger, P. Macaudiere, S. Hull, J. Solid State Chem. 146 (1999) 390-393.

[25] X.C. Fan, X.M. Chen, X.Q. Liu, Chem. Mater. 20 (2008) 4092-4098.

[26] L. Vasylechko, N. Kodama, A. Matkovskii, Y. Zhydachevskii, J. Alloys Compd. 300-301 (2000) 475-478.

[27] R.D. Shannon, R.A. Oswald, J.B. Parise, B.H.T. Chai, P. Byszewski, A. Pajaczkowska, R. Sobolewski, J. Solid State Chem. 98 (1992) 90-98.

[28] F. Chevire, A. Pallu, E. Ray, F. Tessier, J. Alloys Compd. 509 (2011) $5839-5842$.

[29] L. Zhou, J. Shi, M. Gong, J. Rare Earths 24 (2006) 138-142.

[30] R.D. Shannon, Acta Crystallogr. A 32 (1976) 751-767. 
[31] F. Izumi, K. Momma, Solid State Phenom. 130 (2007) 15-20.

[32] K. Momma, Fujio Izumi, J. Appl. Crystallogr. 41 (2008) 653-658.

[33] G.A. Jeffrey, G.S. Parry, R.L. Mozzi, J. Chem. Phys. 25 (1956) 1024-1031

[34] E.J.W. Verwey, Z. Kristallogr. 91 (1935) 317-320. 
Table 1

Band gap energies and lattice parameters for $\mathrm{Gd}_{1+x} \mathrm{Ca}_{1-x} \mathrm{AlO}_{4-x} \mathrm{~N}_{x}$.

\begin{tabular}{ccccc}
\hline$x$ & composition & band gap / eV & \multicolumn{2}{c}{ lattice parameters $^{a}$} \\
& & & $a / \mathrm{nm}$ & $c / \mathrm{nm}$ \\
\hline 0.0 & $\mathrm{GdCaAlO}_{4}$ & 4.46 & $0.3658(2)$ & $1.1994(6)$ \\
0.15 & $\mathrm{Gd}_{1.15} \mathrm{Ca}_{0.85} \mathrm{AlO}_{3.85} \mathrm{~N}_{0.15}$ & 2.96 & $0.3659(3)$ & $1.2059(9)$ \\
0.20 & $\mathrm{Gd}_{1.2} \mathrm{Ca}_{0.8} \mathrm{AlO}_{3.8} \mathrm{~N}_{0.2}$ & 2.94 & $0.3658(1)$ & $1.2067(5)$ \\
0.25 & $\mathrm{Gd}_{1.25} \mathrm{Ca}_{0.75} \mathrm{AlO}_{3.75} \mathrm{~N}_{0.25}$ & 2.91 & $0.3658(2)$ & $1.2072(7)$ \\
\hline
\end{tabular}

altice parameters were calculated from the laboratory XRD data. 
Table 2

Refined structural parameters of $\mathrm{Gd}_{1.2} \mathrm{Ca}_{0.8} \mathrm{AlO}_{3.8} \mathrm{~N}_{0.2}$ in $\mathrm{K}_{2} \mathrm{NiF}_{4}$-type structure.

\begin{tabular}{ccccccc}
\hline Atom & Site & $g$ & $x$ & $y$ & $z$ & $B_{\text {iso }} / \times 10^{-2} \mathrm{~nm}^{2}$ \\
\hline $\mathrm{Al}$ & $2 a$ & 1 & 0 & 0 & $0.0118(9)$ & $0.56(3)$ \\
$\mathrm{Gd} / \mathrm{Ca} 1$ & $2 a$ & $0.614 / 0.386(8)$ & 0 & 0 & $0.3657(4)$ & $0.33(6)$ \\
$\mathrm{Gd} / \mathrm{Ca} 2$ & $2 a$ & $0.606 / 0.394(5)$ & 0 & 0 & $0.6509(4)$ & $0.35(6)$ \\
O/N1 & $4 b$ & & 0 & $1 / 2$ & $0.0151(8)$ & \\
O/N2 & $2 a$ & $0.95 / 0.05^{a}$ & 0 & 0 & $0.8329(8)$ & $0.38(6)^{b}$ \\
O/N3 & $2 a$ & & 0 & 0 & $0.1689(7)$ & \\
\hline
\end{tabular}

$R_{\mathrm{wp}}=5.4 \%, R_{\mathrm{p}}=4.1 \%$. S.G.: $14 \mathrm{~mm}, a=0.365850(1) \mathrm{nm}, c=1.206752(8) \mathrm{nm}$. ${ }^{a}$ Site occupations, $g$, for anion sites were fixed as $0.950 / 0.05 \mathrm{~N}$. ${ }^{b}$ Isotropic displacement parameters, $B_{\text {iso, }}$, for anion sits were analyzed using a constrains: $B(\mathrm{O} / \mathrm{N} 1)=B(\mathrm{O} / \mathrm{N} 2)=$ $B(\mathrm{O} / \mathrm{N} 3)$. 
Table 3

Selected bond lengths $(n m)$ in $\mathrm{Gd}_{1.2} \mathrm{Ca}_{0.8} \mathrm{AlO}_{3.8} \mathrm{~N}_{0.2}$.

\begin{tabular}{|c|c|c|c|}
\hline \multicolumn{4}{|c|}{$\mathrm{Gd}_{1.2} \mathrm{Ca}_{0.8} \mathrm{AlO}_{3.8} \mathrm{~N}_{0.2}$ S.G.: $14 \mathrm{~mm}$} \\
\hline \multirow[t]{3}{*}{ Al (2a) } & $\mathrm{O} / \mathrm{N} 1(4 b)$ & $\times 4$ & $0.18297(2)$ \\
\hline & O/N2 (2a) & $\times 1$ & $0.2160(18)$ \\
\hline & O/N3 (2a) & $\times 1$ & $0.1900(19)$ \\
\hline \multirow[t]{3}{*}{$\mathrm{Gd} / \mathrm{Ca} 1(2 a)$} & $\mathrm{O} / \mathrm{N} 1(4 b)$ & $\times 4$ & $0.2568(8)$ \\
\hline & O/N2 (2a) & $\times 4$ & $0.2617(2)$ \\
\hline & O/N3 (2a) & $\times 1$ & $0.2375(11)$ \\
\hline \multirow[t]{3}{*}{$\mathrm{Gd} / \mathrm{Ca} 2(2 a)$} & $\mathrm{O} / \mathrm{N} 1(4 b)$ & $\times 4$ & $0.2456(8)$ \\
\hline & O/N2 (2a) & $\times 1$ & $0.2197(11)$ \\
\hline & O/N3 (2a) & $\times 4$ & $0.2596(2)$ \\
\hline
\end{tabular}




\section{Figure Captions}

Fig. 1 Crystal structures of $\mathrm{K}_{2} \mathrm{NiF}_{4}$-type oxynitrides: (a) $\mathrm{Nd}_{2} \mathrm{AlO}_{3} \mathrm{~N}(14 \mathrm{~mm})$ and (b) $\mathrm{Sr}_{2} \mathrm{TaO}_{3} \mathrm{~N}(1 / 4 / \mathrm{mmm})$.

Fig. 2 XRD patterns of products obtained from starting mixtures with AIN only as the aluminum source for $\mathrm{Gd}_{1+x} \mathrm{Ca}_{1-x} \mathrm{AlO}_{4-x} \mathrm{~N}_{x}$ at $\mathrm{x}=$ (a) 0 , (b) 0.05 , (c) 0.1 , (d) 0.15, (e) 0.20 , (f) 0.25 , and (g) 0.30 . The product obtained for $\mathrm{x}=0\left(\mathrm{GdCaAlO}_{4},(\mathrm{a})\right)$ was prepared using $\mathrm{y}-\mathrm{Al}_{2} \mathrm{O}_{3}$ as the aluminum source. Diffraction lines marked with diamonds, triangles and circles indicate the $\mathrm{K}_{2} \mathrm{NiF}_{4}$-type $\mathrm{Gd}_{1+x} \mathrm{Ca}_{1-x} \mathrm{AlO}_{4-x} \mathrm{~N}_{x}$, $\mathrm{Gd}_{2} \mathrm{O}_{3}$, and $\mathrm{CaAl}_{2} \mathrm{O}_{4}$ phases, respectively.

Fig. 3 Diffuse reflectance spectra of $\mathrm{Gd}_{1+x} \mathrm{Ca}_{1-x} \mathrm{AlO}_{4-x} \mathrm{~N}_{x}$.

Fig. 4 Observed (+), calculated (solid line) and difference synchrotron XRD profiles for $\mathrm{K}_{2} \mathrm{NiF}_{4}$-type $\mathrm{Gd}_{1.2} \mathrm{Ca}_{0.8} \mathrm{AlO}_{3.8} \mathrm{~N}_{0.2}$. Vertical bars indicate the positions of Bragg reflections.

Fig. 5 Atomic arrangement around $\mathrm{Al}$ and $\mathrm{Gd} / \mathrm{Ca}$ sites in (a) $\mathrm{Gd}_{1.2} \mathrm{Ca}_{0.8} \mathrm{AlO}_{3.8} \mathrm{~N}_{0.2}$ 
$(14 \mathrm{~mm})$ and (b) $\mathrm{GdCaAlO}_{4}(14 / \mathrm{mmm})$. The schematic structure of $\mathrm{GdCaAlO}_{4}$ was drawn using the reported structural parameters [26]. 
Figure $1 \mathrm{Y}$. Masubuchi, et al.

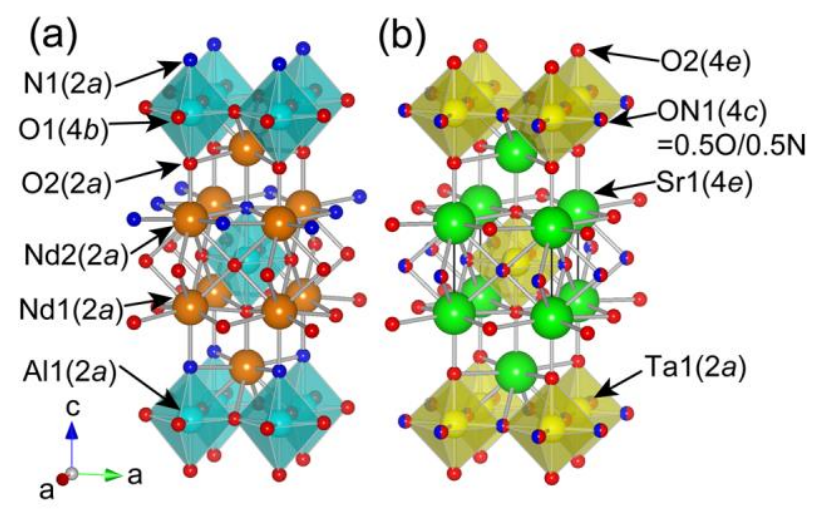

Fig. 1 Crystal structures of $\mathrm{K}_{2} \mathrm{NiF}_{4}$-type oxynitrides: (a) $\mathrm{Nd}_{2} \mathrm{AlO}_{3} \mathrm{~N}(14 \mathrm{~mm})$ and (b)

$\mathrm{Sr}_{2} \mathrm{TaO}_{3} \mathrm{~N}(14 / \mathrm{mmm})$. 
Figure 2 Y. Masubuchi, et al.

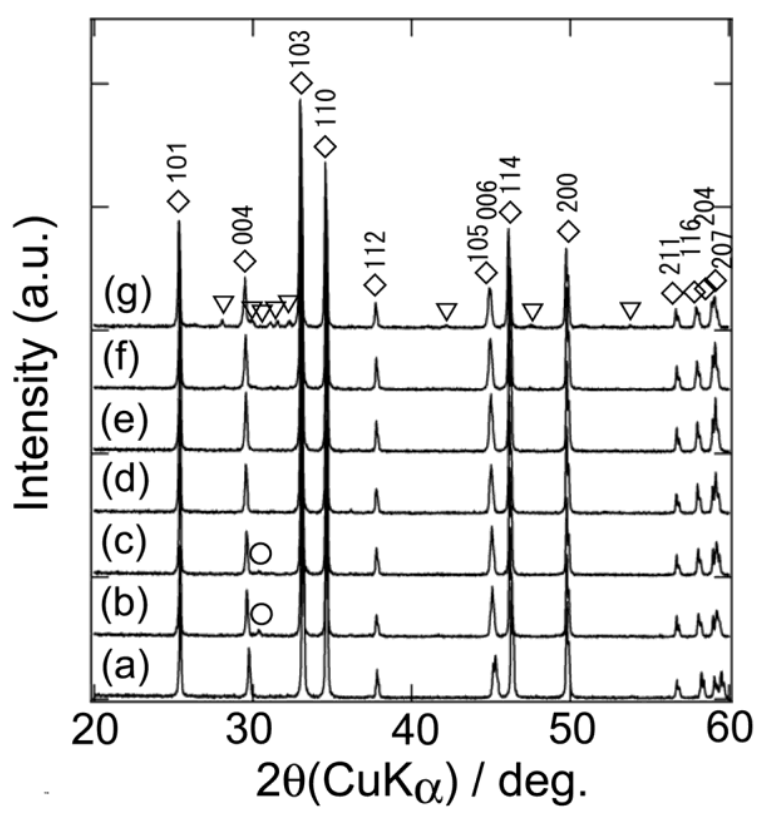

Fig. 2 XRD patterns of products obtained from starting mixtures with AIN only as the aluminum source for $\mathrm{Gd}_{1+x} \mathrm{Ca}_{1-x} \mathrm{AlO}_{4-x} \mathrm{~N}_{x}$ at $\mathrm{x}=$ (a) 0 , (b) 0.05 , (c) 0.1 , (d) 0.15, (e) 0.20 , (f) 0.25 , and $(\mathrm{g}) 0.30$. The product obtained for $\mathrm{x}=0\left(\mathrm{GdCaAlO}_{4},(\mathrm{a})\right)$ was prepared using $\mathrm{y}-\mathrm{Al}_{2} \mathrm{O}_{3}$ as the aluminum source. Diffraction lines marked with diamonds, triangles and circles indicate the $\mathrm{K}_{2} \mathrm{NiF}_{4}$-type $\mathrm{Gd}_{1+x} \mathrm{Ca}_{1-x} \mathrm{AlO}_{4-x} \mathrm{~N}_{x}$, $\mathrm{Gd}_{2} \mathrm{O}_{3}$, and $\mathrm{CaAl}_{2} \mathrm{O}_{4}$ phases, respectively. 
Figure 3 Y. Masubuchi, et al.

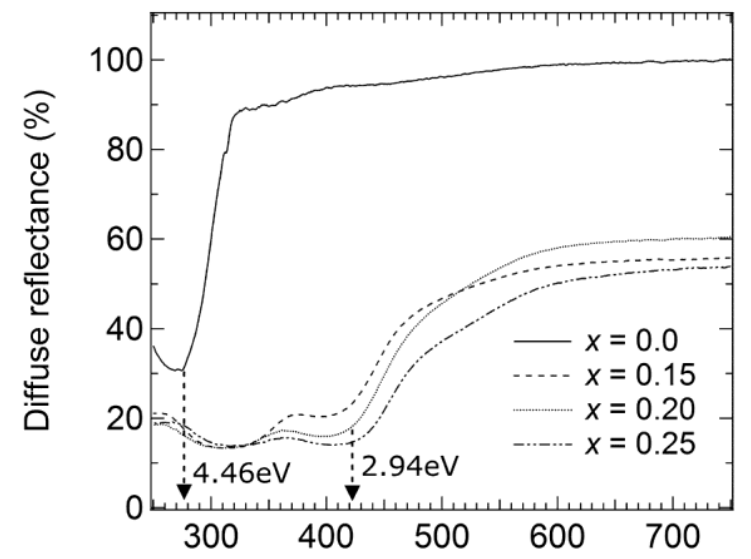

Fig. 3 Diffuse reflectance spectra of $\mathrm{Gd}_{1+x} \mathrm{Ca}_{1-x} \mathrm{AlO}_{4-x} \mathrm{~N}_{x}$. 
Figure 4 Y. Masubuchi, et al.

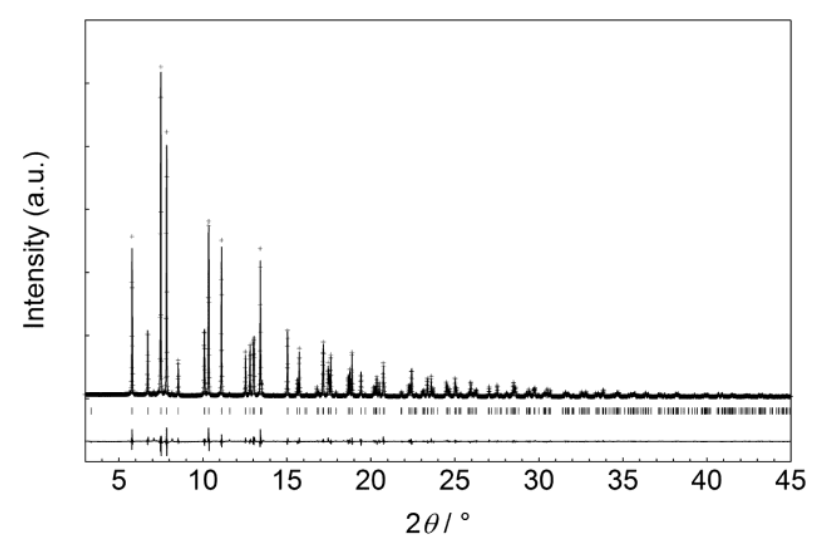

Fig. 4 Observed (+), calculated (solid line) and difference synchrotron XRD profiles for $\mathrm{K}_{2} \mathrm{NiF}_{4}$-type $\mathrm{Gd}_{1.2} \mathrm{Ca}_{0.8} \mathrm{AlO}_{3.8} \mathrm{~N}_{0.2}$. Vertical bars indicate the positions of Bragg reflections. 
Figure 5 Y. Masubuchi, et al.

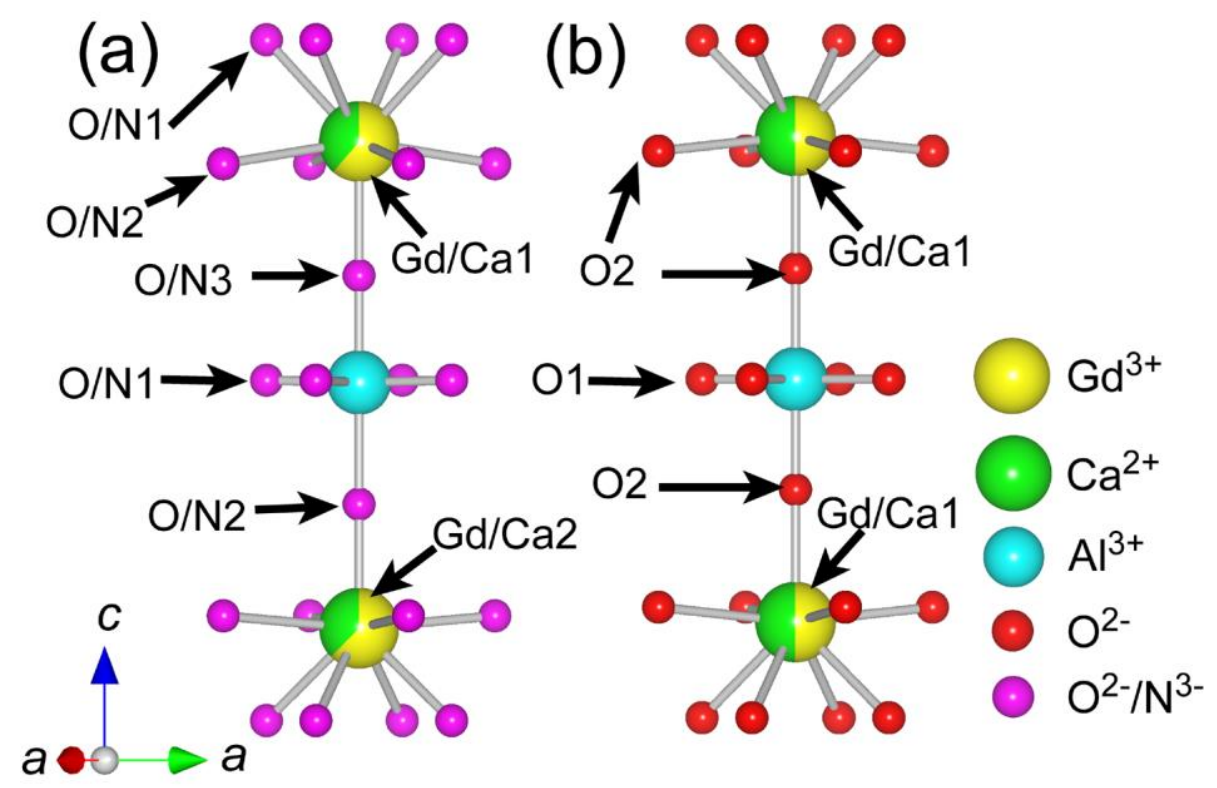

Fig. 5 Atomic arrangement around Al and $\mathrm{Gd} / \mathrm{Ca}$ sites in (a) $\mathrm{Gd}_{1.2} \mathrm{Ca}_{0.8} \mathrm{AlO}_{3.8} \mathrm{~N}_{0.2}$

$(14 \mathrm{~mm})$ and (b) $\mathrm{GdCaAlO}_{4}(14 / \mathrm{mmm})$. The schematic structure of $\mathrm{GdCaAlO}_{4}$ was drawn using the reported structural parameters [26]. 